\title{
OSMOTIC DEHYDRATION OF PINEAPPLE
}

\author{
By
}

\author{
M.B.Shyama Nishanthi
}

This thesis is submitted to the University of Sri Jayawardanapura, Sri Lanka for the award of the degree of Masters of Food Science and Technology in 2006. 


\section{DECLARATION}

The work in this thesis was carried out by me at the University of Sri Jyawardenapura \& Coco Lanaka Ltd., Kanuwana,Ja-Ela under the supervision of professor Arthur Bamunuarachchi \& Mrs. Rangika wijesuriya ( Quality Assurance Manager Coco Lanka Ltd., Renuka Group of companies ) and the report on this has not been submitted to any university for another degree.

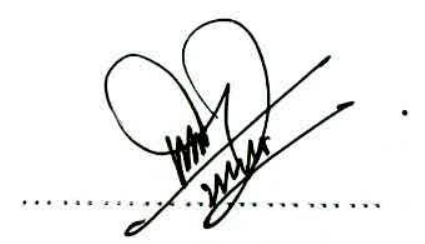

M.B.S.Nishanthi 
We, Professor Arthur Bamunuarachchi and Mrs. Rangika Vijesuriya hereby certify that the statement in the preceding page made by the candidate is true \& that this thesis is suitable for submission for the university for the purpose of evaluation.

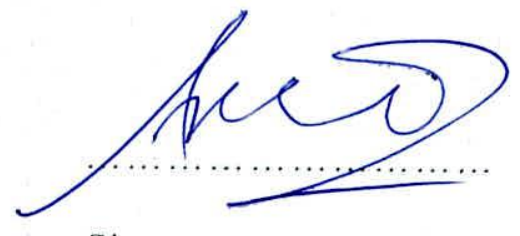

Signature

Proff.A. Bamunuarachchi

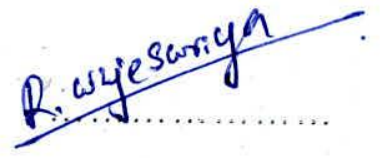

Signature

Mírs.Rangika Wijesuriya

SUPER VISORS :-

PROFESSOR A. BAMUNUARACHCHI,

COORDINATOR OF FOOD SCIENCE \& TECHNOLOGY

TECHNOLOGY PROGRAMMERS,

DEPARTMENT OF FOOD SCIENCE \& TECHNOLOGY,

UNIVERSITY OF SRI JAYAWARDENAPURA,

SRI LANKA.

Mrs. RANGIKA WIJESURIYA,

QUALITY ASSURANCE MANAGER,

COCO LANKA FACTORY,

RENUKA GROUP OF COMPANIES,

KANUWANA,

JA - ELA. 


\section{TABLE OF CONTENT}

\section{LISI OF TABLES}

\section{LIST OF FIGURES}

\section{ACKNOWLEDGEMENT}

\section{ABSTRACT}

\section{CHPTER 1 : INTRODUCTION}

\section{CHPTER 2 : LITREATURE SURVEY}

2.1.1 Pineapples (Annas Comosus)

2.1.2 Cultivars, Production, Harvesting \& users

2.1.2 Botany of Pineapple

\section{CHPTER 3 : MATERIALS \& METHODS}

3.1.0 Selection and preparation of fruit

3.1.1 Selection of the correct Pineapple fruit

3.1.2 Materials

3.1.3 Method

3.1.3 (A) Trial No one

3.1.3 (A) Trial No Two

3.2 Chemical Analysis

3.2.1 Determination of vitamin C

3.2.2 Materials

3.2.3. Method 
3.3.1 Preference test

3.3.2 Materials

3.3.3 Methods

\section{CHAPTER 4: RESULTS \& DISCUSSION}

4.1 Wastage of fruits 28

4.2 Determination of the suitable sugar concentration

4.3 The increase of the brix of the pineapple pieces with time

4.4 The decrease of the brix of sugar solution with

dehydration time in both trial $1 \& 2$

4.5 Loss of moisture \% of pineapple pieces in different sugar series. 30

4.6 Analysis of the final product

4.6.1 Chemical Analysis

4.6.2 Results of the sensory evaluation

4.7 Shelf life study

CHAPTER 5: CONCLUTION

\section{REFERENCES}




\section{LIST OF TABLES}

Table 1 : Result of the brix of pieces in every two hours- Trial 1

Table 2: Result of the brix of pieces in every two hours- Trial 2

Table 3: Time Vs.Brix from initial brix 50- Trial 1

Table 4: Time Vs.Brix from initial brix 60 - Trial 1

Table 5: Time Vs.Brix from initial brix 70- Trial 1

Table 6: Time Vs.Brix from initial brix 50- Trial 2

Table 7: Time Vs.Brix from initial brix 60- Trial 2

Table 8: Time Vs.Brix from initial brix 70- Triai 2

Table 9: Determination of moisture variation with different sugar series

Table 10: Absorbance Vs. Vitamin C (calibration)

Table 11: Vitamin C variation Vs. Different sugar concentrations 


\section{LIST OF FIGURES}

Table 1 : Result of the brix of pieces in every two hours- Trial 1

Table 2: Result of the brix of pieces in every two hours- Trial 2

Table 3: Time Vs.Brix from initial brix 50- Trial 1

Table 4: Time Vs.Brix from initial brix 60 - Trial 1

Table 5: Time Vs.Brix from initial brix 70- Trial 1

Table 6: Time Vs.Brix from initial brix 50- Trial 2

Table 7: Time Vs.Brix from initial brix 60 - Trial 2

Table 8: Time Vs.Brix from initial brix 70- Trial 2

Table 9: Determination of moisture variation with different sugar series

Table 10: Absorbance Vs. Vitamin C (calibration)

Table 11: Vitamin C variation Vs. Different sugar concentrations 


\section{ACKNOWLEDGEMENT}

I wish to thank my supervisor professor Arthur Bamunuarachchi for advising, guiding \& giving suggestions through out the project. And I would like to thank Mirs. Wijesuriya, the quality Assurance Manager, Coco Lanka for granting me permission \& all the supportive activities given to successfully compiete my project. My special thank goes to Mr.Sajeewa Surasinghe, Ms.Nayana Gunathilaka (Executives-Coco Lanka Ltd.), Mir.Upul Jayasinghe (Deputy General Manager - Coco Lanka Ltd.) for heiping me to fulfill my thesis.

I wish to offer my heartiest gratitude to my husband, my parents, my sisters \& the brother for giving me a wonderful support \& for being patience to bear up all the inconveniences made by me not only during the writing of the thesis but aiso for the time period which I was reading for my master degree. 


\title{
Osmotic Dehydration of Pineapple
}

By

\author{
M.B.S.Nishanthi
}

\begin{abstract}
Osmotic dehydration is a process of continual removal of water from the pineapple tissue without damaging the pineapple tissue. For this, a series of concentrated sugar solutions have been used. By keeping pineapple tissues in a concentrated sugar solution enables the water molecules in the pineapple tissue to remove from the tissue. Instead of exposing the pineapple tissues directly to a high concentrated sugar solution, in this project it has tried to gradually increase the concentration of the sugar solution. Hence the osmotic pressure in side the tissue increases gradually leading to remove water gradually from the pineapple tissues.

If a live tissue is exposed directly to a high concentrated sugar solution, water molecules in the tissue come out rapidly and sugar molecules go in to the tissue very fast. It causes heavy damages to the tissue. The texture of the tissue changes, hence the natural taste and colour of the tissue changes. And also it leads susceptible micro organisms to grow on the tissue surface and deteriorate the pineapple tissue. In this experiment it has tried to increase the osmotic pressure of the pineapple tissue without damaging the tissue.
\end{abstract}

In this experiment two trials were done named as trial No. one and two using the same sugar concentrations. In trial no. one the pineapple pieces were put in to a sugar solution which was at room temperature. In trial No. two, the pineapple pieces were put in to a 
sugar solutions which were at $60{ }^{\circ} \mathrm{C}$. In trial No. two increased temperature of the solution cause the molecules in the solution to be little more volatile than the trial No. one. It enables the water molecules in the solution to move faster in the solution and remove from the pineapple tissue. When comparing the time consumption for the osmotic pressure of pineapple tissues to become constant, it is clear that trial No. one takes more time to become constant. Exposing of pineapple tissues for a long period of time in a sugar solution can be vulnerable for such tissues, since there are a lot of Yeast and Mould cells in the atmosphere they can easily contaminate the product causing differences in colour, taste and texture in the final product. Since the method described in trial No. one takes more time for the processing, it is not economical. When compared to trial No. one, trial No. two takes lesser processing time and that is economical.

A shelf life study was conducted for both samples produced from trail No. one and trial No. two. The sample taken from trail No. one went out of microbiological and organoleptical parameters by three months. And the sample produced from trial No. two was acceptable after six months period also.

A sensory analysis was conducted between two samples (one from the sample produced of trial No. two and the other was produced by introducing fresh pineapple pieces to $70 \%$ brix) concentrated sugar solution and followed by other steps as the trial No. two. The sample produced by trial No. two was the most preferred. OPP material was selected as the appropriate packing material. 


\section{CHAPTER 1}

\section{INTRODUCTION}

Due to the seasonal nature and perish ability of fruits, processing and preserving them has become a necessity for consumption and long term shelf life. Increasing of solute concentration of food products by means of product immersion in a hypertonic solution (sugar, salt, sorbitol or glycerol) is known as osmotic dehydration Osmotic dehydration has become most popular as a technique for producing intermediate moisture foods or as a pre drying treatment to reduce energy consumption and heat damage.

Osmotic dehydration is a complex and dynamic mass transfer process. Free water in the pineapple tissue permeates in to the high concentrated sugar solution through the cell membrane due to high osmotic pressure and low water activity of the sugar solution. The process can reduce the water amount of pineapple tissue by $50 \%$. Osmotic dehydration process is affected by the concentrations of sugar solutions and the temperature of the sugar solution.

When the live tissue is exposed to high concentration of sugar solution suddenly the cells in the external layer of the tissue gets contacted with the sugar solution. Osmosis takes place rapidly in those cells and cells get shrinked. Hence the middle cell layers of the tissue are not undergone proper osmosis. Hence the tissue gets damaged and the natural freshness is not preserved. 
In this experiment, it was tried to protect pineapple tissues without damaging and preserving the taste, texture and colour. Hence a series of sugar solutions were introduced gradually to pineapple pieces. Little bit of heat $\left(\right.$ at $60^{\circ} \mathrm{C}$ ) was given to facilitate sugar molecules to penetrate the pineapple tissue easily.

\section{AIM OF THE STUDY}

To introduce a confectionary with a natural base.

To make pineapple available in the market during the off season also.

To work out the appropriate sugar concentration series and the time consumption for osmotic dehydration.

To know the correct time, temperature combination for drying.

To find out the shelf life of the particular product.

To investigate the acceptance by the consumer. 


\section{CHAPTER 2}

\section{LITREATURE SURVEY}

\subsection{Pineapple (Ânanas cosmosus)}

The pineapple is not native to Sri Lanka. Its motherland is southern Brasil. From there it is spreaded to India, Sri Lanka, South \& Central America. It is consumed as a fruit as well as a vegetable. It gives sweet taste, with little sour. In some varieties sour taste is prominent than the sweet taste. People consume it as it is, cooked with some spies, as jams, as drinks ..etc.

Pineapple has some allergen effect for some people.

\subsubsection{Production, Harvesting \& Uses.}

Pineaples are drought - tolerant

\section{Production}

Pineapple likes lot of sun \& grow well in tropical regions. The world production of pineapple is 14.34 million metric tones (MMT) in 1980 . They are successfully grown \& marketed to fresh market from Hawaii, Honduras, Mexico \& Nicaragua. 


\section{Harvesting}

When the fruit is about six months old, about four months after flowering has occurred, changes begin to occur. The colour of the shell changes from green to rich gold. The colour change of the shell occurs first at the bottom of the fruit $\&$ moves up wards. During this change, the fruit becomes sweeter $\&$ the colour of the flesh changes from white to yellow. The fruit may weigh from two to four pounds. When the fruit is golden half way up it can be picked \& processed.

\section{Uses}

Pineapple is one of the world favourite tropical fruits. can buy from the market the whole pineapple fruit or fresh pineapple that is already cut $\&$ ready to eat.

Canned pineapple is another easy way to eat pineapple. Canned pineapple comes in so many fun shapes \& sizes as pineapple slices or rings, pineapple chunks or tit bits \& crushed pineapple. Also can be present in shapes of animals. In cans pineapples may be in its own juice or it can be in light or heavy syrups.

Pineapple juice is another was to enjoy pineapple. It can be consumed its own or mixed with other juice. Pineapple is fortified with Vitamin C. 
Pineapple chutneys are very popular appetizers. Plain pineapple or pineapple mixed with any other fruit varieties, Deciccated coconuts ..ets gives wonderful taste.

Dehydrated pineapple is another method of pineapple processing. It can be kept for more than one year if it is processed well \& packed well. It can be consumed as it is or can consume after re hydration or can mix with puddings as a food decorators.

\subsubsection{Botany of pineappie}

\section{Growth habit}

The pineapple is the leading edible member of the family Bromeliaceae which embraces about 2,000 species, mostly epiphytic and many strikingly ornamental. Now known botanically as Ananas comosus

\section{Description}

The pineapple plant is a terrestrial herb $21 / 2$ to $5 \mathrm{ft}(.75-1.5 \mathrm{~m})$ high with a spread of 3 to $4 \mathrm{ft}$ (.9-1.2 m); a very short, stout stem and a rosette of waxy, straplike leaves, longpointed, 20 to 72 in $(50-180 \mathrm{~cm})$ long; usually needle tipped and generaily bearing sharp, up curved spines on the margins. The leaves may be all green or variously striped with red, yellow or ivory down the middle or near the margins. At blooming time, the stem elongates and enlarges near the apex and puts forth a head of small purple or red flowers, 